\title{
KAJIAN \\ HUBUNGAN KUAT LENTUR DENGAN KUAT TEKAN BETON
}

Suhendra

\begin{abstract}
Abstrak
Perkerasan kaku (rigid pavement) saat ini hampir di semua ruas jalan nasional, provinsi maupun kabupaten digunakan sebagai pengganti perkerasan lentur (flexible pavement). Salah satu kontrol kualitas perkerasan kaku beton semen adalah nilai kuat lenturnya ( $\mathrm{fr}=45 \mathrm{~kg} / \mathrm{cm}^{2}$ pada umur 28 hari) sebagaimanan yang tercantum dalam Spesifikasi Umum Binamarga tahun 2010 revisi 3 yang diedarkan pada tahun 2014. Spesifikasi ini tidak lagi mengatur nilai kuat tekan beton semen yang digunakan pada perkerasan kaku. Hal ini merupakan suatu tantangan bagi dunia pelaksanaan konstruksi karena selama ini pengadaan beton semen adalah berdasarkan mutu kuat tekannya. Formula yang ada di SNI 2847:2013 tentang beton bahwa $\mathrm{fr}=0,62 \square \sqrt{ } \mathrm{fc}$ '. Sementara para pelaksana konstruksi umumnya masih menggunakan spesifikasi binamarga revisi sebelumnya yang memuat mutu beton (K-350), sehingga mutu lentur pada umumnya tidak tercapai. Penelitian ini melingkupi nilai hasil uji lentur yang dilakukan di laboratorium fakultas tekni terhadap balok yang disediakan oleh pihak ketiga yang menggunakan jasa lab., serta benda uji yang dibuat di laboratorium. Hasil uji menunjukkan bahwa terbukti ada korelasi antara kuat lentur terhadap kuat tekan beton. Hubungannya kurang lebih sama dengan formula yang tercantum dalam SNI beton.
\end{abstract}

Kata kunci: Beton, Kuat lentur, Kuat Tekan, Spesifikasi Binamarga 2010 rev. 3

\begin{abstract}
Currently, rigid pavement in almost all national, provincial and district roads is used instead of flexible pavement. One of the rigid concrete pavement quality controls is the flexural strength ( $\mathrm{fr}=45 \mathrm{~kg} / \mathrm{cm}^{2}$ at 28 days) as stated in the General Specification of Binamarga year 2010 revision 3. This specification no longer regulates the value of compressive strength of the rigid pavement. This is a challenge for the construction's practicians in implementation of the specification, because during this time the procurement of cement concrete is based on the compressive strength. The formula is in SNI 2847: 2013 on concrete that fr = $0,62 \square \sqrt{ } f_{c}$. While the construction practitioners generally still use the binamarga specifications of previous revisions that contain the quality of concrete (K-350), so that the quality of bending in general is not achieved. This research covers the value of bending test results conducted in the Engineering Laboratory on beams provided by third parties using lab services, as well as test specimens made in the laboratory. The test results show that there is a correlation between the flexure strength to the compressive strength of the concrete. The relationship is more or less the same as the formula contained in SNI concrete.
\end{abstract}

Keywords: Concrete, Flexure strength, compressive strength, Binamarga Specs 2010 rev. 3

\section{PENDAHULUAN}

Pekerjaan perkerasan kaku (rigid pavement), atau dalam buku spesifikasi umum tahun 2010 seksi 5.3 dinamai dengan Perkerasan Beton Semen saat ini hampir secara menyeluruh diterapkan di ruas jalan dalam provinsi Jambi khususnya dan Indonesia secara umum. 
Kuat lentur beton minimum untuk perkerasan beton semen menurut Buku Spesifikasi Umum Edisi 2010 (revisi 3) secara umum tidak jauh berbeda dengan edisi sebelumnya (revisi 2 dan 2010). Kuat lentur minimum pada umur beton 28 hari adalah Fs $=45 \mathrm{~kg} / \mathrm{cm}^{2}$. SNI 2847:2013 tentang Persyaratan Beton Struktural untuk Bangunan Gedung menyebutnya sebagai modulus ruptur, fr. Namun pada edisi revisi 3 ini tidak lagi mencantumkan nilai kuat tekan beton minimum, sebagaimana tercantum pada buku spesifikasi umum 2010. Pada prakteknya, hal ini menjadikan pengujian kuat lentur beton sebagai persyaratan dalam penerimaan hasil pekerjaan. Namun disisi lain dalam hal pembuatan campuran beton yang selama ini mengacu pada kuat tekan, menjadi tantangan bagi pelaksana yang harus melakukan trial mix sedemikian rupa sehingga kuat lentur $45 \mathrm{~kg} / \mathrm{cm}^{2}(4,4 \mathrm{MPa})$ tercapai.

Mengacu pada nilai kuat lentur beton (fr) berdasarkan nilai kuat tekannya (fc'), SNI 2847:2013 telah menyatakan hubungannya dengan suatu formula, yakni $\mathrm{fr}=0,62 \square \sqrt{ } \mathrm{fc}^{\prime}(\square=1,0$ untuk beton normal). Menilik nilai kuat tekan minimum dan kuat lentur yang tercantum dalam buku Spesifikasi Umum 2010, tidak terpenuhi korelasi sebagaimana formula yang tercantum dalam SNI 2847:2013.

Penelitian ini bermaksud untuk mengkaji hubungan antara kuat tekan beton dengan kuat lenturnya, sehingga diperoleh pedoman dalam menentukan harga satuan pekerjaan beton yang realistis dan sesuai. Penelitian dilakukan dengan melakukan kajian terhadap hasil-hasil pengujian kuat lentur dari berbagai balok beton dari berbagai sumber yang dilakukan pengujiannya di laboratorium Fakultas Teknik Unbari, dan hasil uji yang dirancang sendiri.

Tujuan dari penelitian yang dilakukan adalah:

1. Mendapatkan nilai kuat tekan dan kuat lentur benda uji yang diuji di laboratorium Fakultas Teknik Unbari.

2. Mendapatkan nilai kuat lentur dari benda uji balok yang dirancang sendiri berdasarkan mutu kuat tekannya.

3. Mendapatkan hubungan kuat lentur dengan kuat tekan.

Pengujian terhadap benda uji yang bersumber dari luar adalah benda uji yang berasal dari penyedia jasa konstruksi. Dalam hal ini nilai kuat tekan rencana diperoleh dari informasi penyedia jasa tersebut. Benda uji yang dirancang sendiri dibuat berdasarkan mutu kuat tekan. Rencana campuran dibuat berdasarkan SNI 03-2834-2002.

Manfaat dari penelitian ini adalah:

1. Terwujudnya pemahaman mengenai nilai kuat lentur balok yang bisa diperoleh dari nilai kuat tekannya.

2. Sebagai bahan masukan dan koreksi dalam penentuan mutu beton pada buku Spesifikasi Umum Binamarga khususnya seksi perkerasan beton semen.

\section{TINJAUAN PUSTAKA}

Rigid pavement atau perkerasan kaku terdiri dari suatu slab beton - dengan atau tanpa tulangan - yang dihamparkan langsung pada subgrade atau base course. Bisa juga berupa slab beton yang terlebih dahulu dicetak pada tempat lain dan setelah mengeras baru diletakkan pada subgrade atau base course tersebut.

Teori-teori mengenai perencanaan perkerasan kaku yang ada pada umumnya berdasarkan pada teori yang dikembangkan oleh Westergaard. Baik cara perhitungan menurut Portland Cement Association (PCA), Corp Of Engineers $(C O E)$, Wire Reinforcement Institute (WRI) dan juga cara perhitungan perkerasan 
kaku dari Departemen Pekerjaan Umum. Teori-teori tersebut memperhitungkan nilai CBR lapisan di bawah rigid pavement. Namun sesuai spesifikasi umum 2010, uji kuat lentur mengacu pada SNI 4431:2011, dimana uji lentur berupa lentur pada balok di atas dua tumpuan.

\subsection{Kuat Lentur Balok}

Lentur adalah keadaan gaya kompleks yang berkaitan dengan melenturnya elemen (balok) sebagai akibat adanya beban transversal. Aksi lentur menyebabkan serat pada permukaan elemen memanjang mengalami tarik dan tekan. Tegangan ini bekerja tegak lurus pada permukaan penampang struktur .

Kekuatan elemen (penampang) yang mengalami lentur tergantung pada distribusi material pada penampang, juga jenis materialnya. Sebagai respon (reaksi) atas adanya lentur yang bekerja pada penampang struktur maka penampang akan memberikan gaya perlawanan (aksi) untuk mengimbangi gaya tarik dan tekan yang terjadi pada penampang. (Tri Mulyono, 2003)

Beban-beban yang bekerja pada struktur, baik yang berupa beban gravitasi (berarah vertikal) maupun beban-beban lain, seperti beban angin (dapat berarah horizontal), atau juga beban karena susut dan beban karena perubahan temperatur, menyebabkan adanya lentur dan deformasi pada elemen struktur.

Lentur pada balok merupakan akibat dari adanya regangan yang timbul karena adanya beban luar. (E. G. Nawy,2009). Apabila bebannya bertambah, maka pada balok terjadi deformasi dan regangan tambahan yang mengakibatkan timbulnya (atau bertambahnya) retak lentur di sepanjang bentang balok. Bila bebannya semakin bertambah, pada akhirnya dapat mengakibatkan keruntuhan elemen struktur. Pada saat beban luar mencapai taraf pembebanan demikian disebut keadaan batas keruntuhan karena lentur. Karena itu perencana harus mendisain penampang elemen pada balok sedemikian rupa sehingga tidak terjadi retak yang berebihan pada saat beban kerja, dan masih mempunyai keamanan yang cukup dan kekuatan cadangan untuk menahan beban dan tegangan tanpa mengalami keruntuhan.(E. G Nawy, 2009)

Dengan demikian kuat tekan lentur dapat didefinisikan kemampuan penampang struktur (balok beton) untuk menahan gaya dengan arah tegak lurus dengan sumbu benda uji sampai benda uji patah (gambar 1)

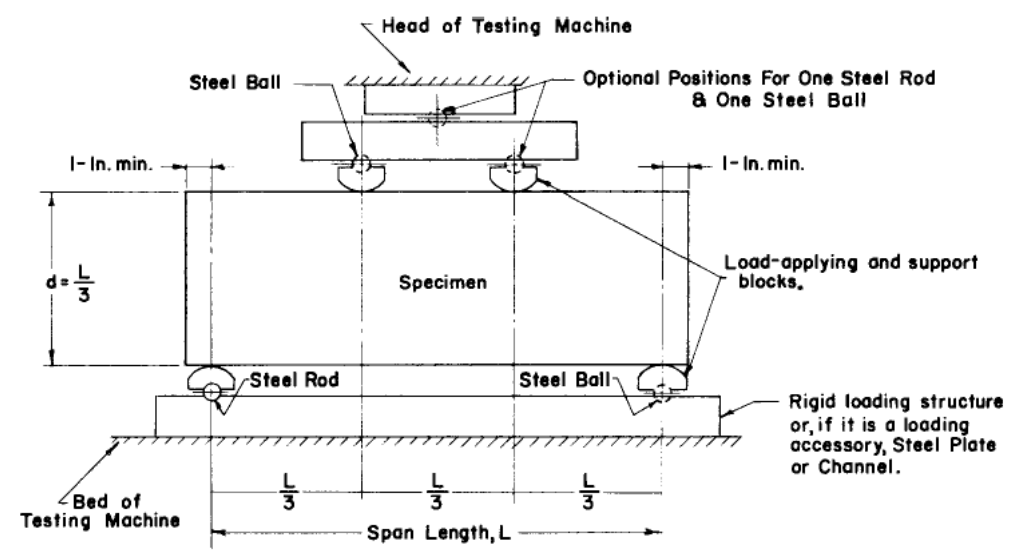

Gambar 1. Skematik pengujian kuat lentur.(ASTM C78) 


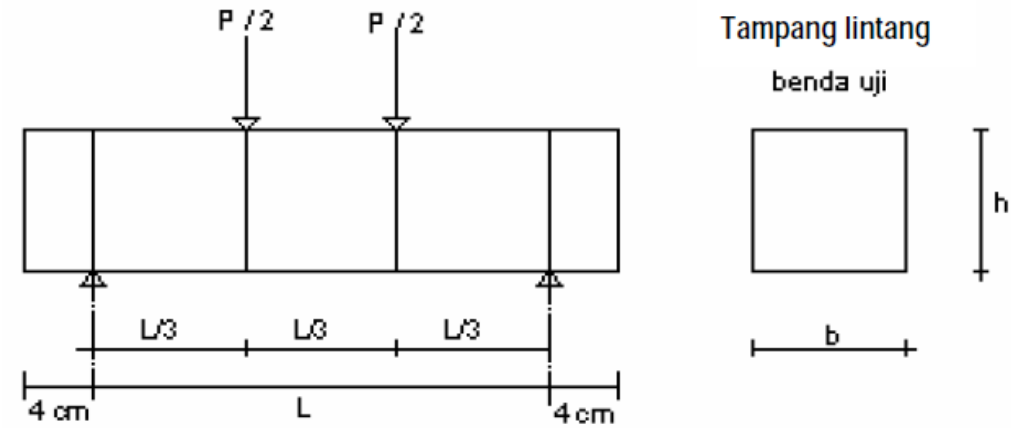

Gambar 2. Garis-garis perletakan dan pembebanan (SNI 4431:2011)

Kuat lentur beton, fr dihitung dengan ketentuan sebagai berikut.

a. Benda uji patah di bagian tengah pada $1 / 3$ jarak titik perletakan pada bagian tarik dari beton, maka beton dihitung dengan rumus :

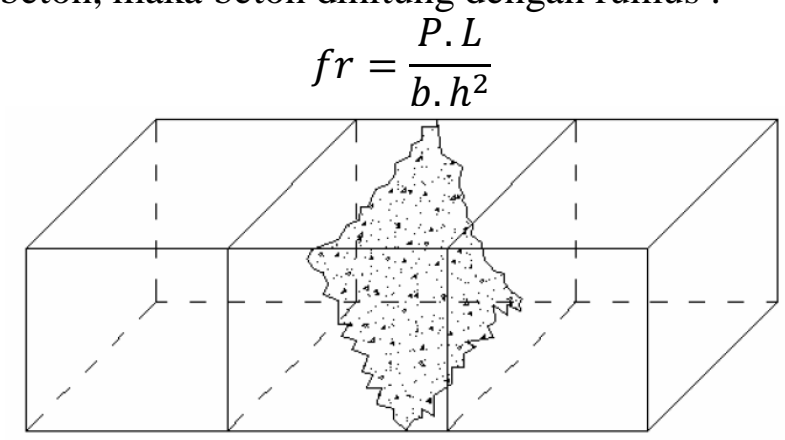

Gambar 3. Patah pada pusat $1 / 3$ bentang (L)

b. Benda uji patah di luar pusat (di luar daerah $1 / 3$ jarak titik perletakan) dibagian tarik beton, dan jarak antara titik pusat dan titik patah kurang dari $5 \%$ dari panjang titik perletakan maka kuat lentur beton dapat dihitung dengan rumus :

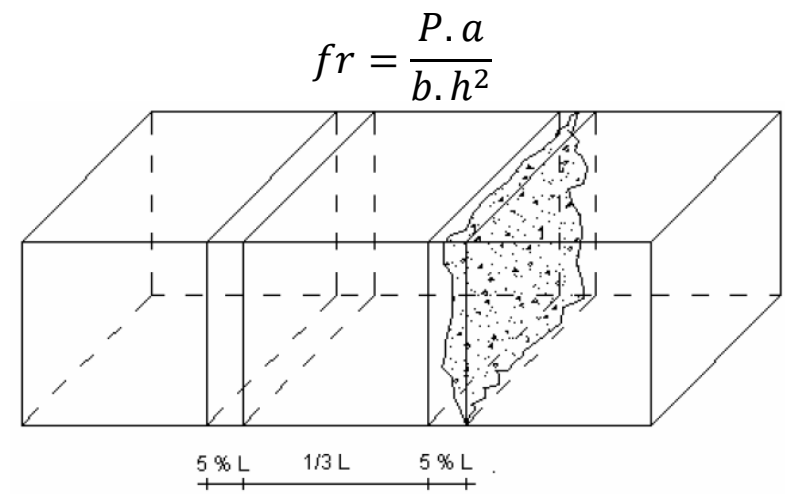

Gambar 4. Patah di luar 1/3 bentang (L) dan garis patah $<5 \%$ dari bentang

Dimana :

fr : Kuat lentur benda uji (MPa)

$\mathrm{P}$ : Beban maksimum pada saat pengujian $(\mathrm{N})$

$\mathrm{L}:$ Jarak bentang antara dua garis perletakan $(\mathrm{mm})$

$\mathrm{b}$ : Lebar patah arah horizontal $(\mathrm{mm})$

$\mathrm{h}$ : lebar patah vertikal (mm)

a : jarak rata-rata antara tampang lintang patah dan tumpuan luar terdekat diukur 4 tempat pada sisi tarik benda uji (mm)

c. Benda uji yang patahanya diluar 1/3 lebar pusat pada bagian tarik beton dan jarak antara titik pembebanan dan titik patah lebih dari $5 \%$ bentang maka 
hasil pengujian dinyatakan batal dan diulang kembali dengan benda uji yang baru.

Menurut Spesifikasi Umum Binamarga tahun 2010 revisi 3 Divisi 5 seksi 5.3 (Perkerasan Beton Semen), nilai kuat lentur minimum perkerasan kaku pada umur 28 hari adalah $\mathrm{Fs}=45 \mathrm{~kg} / \mathrm{cm}^{2}$. Jika dalam satuan internasional adalah sama dengan $\mathrm{fr}=4,4 \mathrm{MPa}$. Lebih lanjut di Divisi 5 Seksi 5.3 bagian $11 \mathrm{c}$ ) mengenai kekuatan lentur perkerasan beton semen, disyaratkan kekuatan pada umur 7 hari. Kekuatan lentur pada umur 7 hari minimal $80 \%$ dari kuat lentur lapangan yang terjadi.

2.2. Kuat Tekan

Kuat Tekan Beton mengindentifikasikan mutu dari suatu struktur. Semakin tinggi tingkat kekuatan struktur yang dikehendaki, semakin tinggi pula mutu beton yang diperlukan. Kuat tekan beton dinotasikan sebagai berikut.

$$
f c^{\prime}=\frac{P}{A}
$$

$f c^{`}$ : Kuat tekan beton (MPa).

$\mathrm{P}$ : Beban uniaksial tekan hancur $(\mathrm{N})$

A : Luas bidang tekan benda uji $\left(\mathrm{mm}^{2}\right)$

Benda uji berbentuk silinder berukuran diameter $150 \mathrm{~mm}$ dan tinggi $300 \mathrm{~mm}$.

Menurut Spesifikasi Umum Binamarga tahun 2010 revisi 3 Divisi 7 seksi 7.1 (Beton), mutu beton untuk penggunaan sebagai perkerasan beton semen adalah jenis beton mutu sedang dengan rentang fc' adalah 20 sampai $45 \mathrm{MPa}$.

\section{METODOLOGI PENELITIAN}

Hasil uji kuat tekan dan kuat lentur pada benda uji yang dibuat sendiri serta benda uji yang berasal dari penyedia jasa konstruksi pada rentang waktu penelitian digunakan sebagai data penelitian ini.

Benda uji kuat tekan berupa silinder beton berukuran diameter $150 \mathrm{~mm}$ dan tinggi $300 \mathrm{~mm}$. Benda uji balok lentur berupa balok beton berukuran $150 \mathrm{~mm}$ x 150 $\mathrm{mm} \times 600 \mathrm{~mm}$.

Pengujian kuat tekan mengacu pada SNI 03-1974-1990 dan ASTM C 39M. Pengujian kuat lentur mengacu pada SNI 4431: 2011 dan ASTM C 78. Perencanaan campuran beton untuk uji kuat tekan mengacu pada SNI 03-2834-2002.

Alat uji yang digunakan tersedia di Laboratorium Fakultas Teknik Unbari.

\section{HASIL PENELITIAN DAN ANALISIS}

Hasil uji menunjukkan bahwa nilai kuat lentur pada umur 28 hari meningkat tidak terlalu tinggi dibanding kuat lentur umur 7 hari. Kuat tekan umur 28 hari jauh lebih besar dibanding kuat tekan umur 7 hari.

Tabel 1. Hasil uji Kuat Tekan rata-rata dan Kuat Lentur rata-rata benda uji

\begin{tabular}{|c|c|c|c|c|c|}
\hline \multirow[b]{2}{*}{ No } & \multirow[b]{2}{*}{$\begin{array}{c}\text { Penyedia } \\
\text { Benda } \\
\text { Uji }\end{array}$} & \multirow[b]{2}{*}{$\begin{array}{l}\text { Umur } \\
\text { (Hari) }\end{array}$} & \multicolumn{2}{|c|}{ Hasil Uji (MPa) } & \multirow{2}{*}{$\begin{array}{c}\text { Kuat lentur } \\
\text { berdasarkan } \\
\text { nilai uji kuat tekan } \\
\text { fr }= \\
0,62 \sqrt{\mathrm{fc}^{\prime}}(\mathrm{MPa})\end{array}$} \\
\hline & & & $\begin{array}{c}\text { kuat } \\
\text { tekan, } \\
\text { fc }^{\prime}\end{array}$ & $\begin{array}{c}\text { kuat } \\
\text { lentur, fr }\end{array}$ & \\
\hline 1 & Peneliti & 7 & 15,1 & 3,2 & 2,4 \\
\hline 2 & $\begin{array}{l}\text { PT KDJP } \\
\text { PT }\end{array}$ & 7 & 13,9 & 1,7 & 2,3 \\
\hline 3 & Hanro & 7 & 29,2 & 1,7 & 3,4 \\
\hline 4 & Peneliti & 28 & 36,7 & 3,8 & 3,8 \\
\hline
\end{tabular}


Sumber: Hasil Penelitian, data diolah, 2016

Hasil uji lentur benda uji umur 7 hari (benda uji yang dibuat di laboratorium), menunjukkan nilai kuat lentur yang lebih besar dibanding nilai yang diperoleh berdasarkan nilai uji kuat tekan $\left(\mathrm{fr}=0,62 \sqrt{ } \mathrm{fc}^{\prime}\right)$. Hal ini sesuai dengan yang dinyatakan oleh $H$. S. Lew and T. W. Reichard dalam James G. MacGregor (2012) bahwa nilai kuat lentur beton meningkat dengan cepat dibanding kuat tekannya.

Hasil uji lentur pada umur 7 hari memenuhi kriteria minial $80 \%$ dari kuat lentur lapangan yang terjadi. Hasil ini berlaku untuk benda uji lentur yang dibuat di laboratorium dan dengan perawatan standar.

Nilai kuat lentur umur 7 hari untuk benda uji yang disediakan oleh PT KDJP dan PT Hanro menunjukkan nilai sebaliknya. Hal ini terjadi karena kontrol selama pembuatan benda uji dan perawatannya di lapangan kurang sesuai dengan standar yang berlaku.

Hubungan kuat lentur terhadap kuat tekan secara keseluruhan hanya berlaku secara akurat untuk uji umur 28 hari. Untuk uji umur kurang 28 hari, nilai kuat lentur menggunakan formula berdasarkan nilai hasil uji kuat tekan relatif lebih kecil.

Berdasarkan hasil uji tekan dan lentur di atas, terlihat bahwa hubungan kuat lentur terhadap kuat tekannya adalah bersesuaian dengan formula yang tercantum di SNI 2847:2013, yakni fr $=0,62 \sqrt{ } \mathrm{fc}^{\prime}$. Sehingga, Secara keseluruhan, penggunan beton mutu sedang sesuai spesifikasi umum binamarga tahun 2010 revisi 3 divisi 7 seksi 7.1 untuk perkerasan beton semen tidak akan menghasilkan kekuatan minimum untuk kuat lentur pada umur 28 hari $(\mathrm{Fs}=\mathrm{fr}=4,4 \mathrm{MPa})$. Hal ini karena untuk beton $\mathrm{fc}^{\prime}=45 \mathrm{MPa}$ (batas atas beton mutu sedang) hanya menghasilkan kuat lentur sebesar $\mathrm{fr}=0,62 \sqrt{ } 45=4,15 \mathrm{MPa}$.

\section{Kesimpulan}

1. Berdasarkan hasil pembuatan benda uji lentur dan tekan di Laboratorium, diperoleh hubungan yang sesuai antara kuat lentur (fr) dengan kuat tekan (fc'), sebagaimana yang tercantum dalam SNI 2847:2013. Formula ini ( $\mathrm{fr}=$ $\left.0,62 \sqrt{ } \mathrm{fc}^{\prime}\right)$ berlaku untuk umur uji 28 hari.

2. Kuat lentur balok umur uji kurang 28 hari nilainya relatif lebih kecil jika menggunakan formula SNI 2847:2013 dibanding hasil uji balok lenturnya sendiri.

3. Kuat lentur minimum yang disyaratkan dalam spesifikasi umum tahun 2010 yakni fs $=45 \mathrm{~kg} / \mathrm{cm}^{2}(\mathrm{fr}=4,4 \mathrm{MPa})$ tidak terpenuhi untuk mutu beton sedang (fc`20 sampai $45 \mathrm{MPa}$ )

\section{Saran}

1. Berdasarkan kriteria pengaturan mutu beton (kuat tekan) di divisi 7 seksi 7.1 dan kekuatan lentur minimum perkerasan beton semen di divisi 5 seksi 5.3, dalam spesifikasi umum binamarga tahun 2010 (baik edisi awal ataupun sampai revisi 3) maka diperlukan peninjauan kembali terhadap spesifikasi umum dimaksud agar terjadi sinkronisasi antara kuat tekan dengan kuat lentur beton sebagaimana yang telah diformulasikan dalam SNI 2847:2013 dan dibuktikan dalam penelitian ini.

2. Perlakuan pada pekerjaan perkerasan beton semen di lapangan harus mengikuti prosedur dan tatacara yang sesuai. Terlihat dengan perlakuan saat 
pembuatan dan tanpa perawatan benda uji di lapangan, menghasilkan kekuatan lentur yang jauh dari diharapkan.

3. Perlu peninjauan kriteria kuat lentur untuk rigid pavement dalam Spesifikasi Umum Bina Marga. Kuat Lentur untuk rigid pavement semestinya dipengaruhi juga oleh base course, sedangkan uji lentur menurut SNI 4431:2011 tidak mengikutkan hal tersebut

\section{DAFTAR PUSTAKA}

ACI 360R - 92, Design Of Slabs On Grade,.ACI Manual Of Concrete Practice Part 2, 1995

ACI Manual of Concrete Practice Part 1, 1995

ASTM, Concrete and Aggregates, Annual Book of ASTM Standard Vol. 04.02, American Society for Testing and Materials, Philadelphia, 1993

Child, L.D., A model Study of Slab Action in Concrete Pavement, Highway Research Board, Proceedings $25^{\text {th }}$ Annual Meeting, 1945.

Departemen Pekerjaan Umum, Pedoman Perencanaan Pembebanan Jembatan Jalan Raya, SNI No. 1725 - 1989 - F, Yayasan Badan Penerbit PU, 1989.

Ditjen Binamarga, Spesifikasi Umum, edisi 2010 revisi 1, Kementerian PU, 2012

Ditjen Binamarga, Spesifikasi Umum, edisi 2010 revisi 2, Kementerian PU, 2012

Ditjen Binamarga, Spesifikasi Umum, edisi 2010 revisi 3, Kementerian PU, 2014

Ditjen Binamarga, Spesifikasi Umum, edisi 2010, Kementerian PU, 2011

Hewes, L.I., American Highway Practice, Vol. II, John Wiley \& Sons Inc., 1942.

LAPI - ITB, Final Report Of Stage I, Utilization and Beneficial Uses of Tailings for Construction Materials, March 1998.

Mulyono, T. 2003. Teknologi Beton, Penerbit Andi Offset, Yogyakarta.

Nawy, E. G., 2009. Beton Bertulang. Erlangga. Jakarta

Paxon, G. S., Factors Influencing The Stress In Concrete Pavement From Applied Loads, Oregon State Highway Department, $19 .$.

Ringo, B. C., Anderson, R.B., Designing Floor Slabs On Grades, 2nd Ed.,The Aberdeen Group, 1996.

SNI 03-1974-1990, Metode Pengujian Kuat Tekan Beton

SNI 03-4431-2011, Metode Pengujian Kuat Lentur Beton Normal Dengan Dua Titik Pembebanan

Westergaard H.M., Stresses in Concrete Pavements Computed by Theoritical Analysis, Public Roads, Vol. 7, No. 2, April, 1926

Yoder, E.J., Witczak, M.W., Principles Of Pavement Design, $2^{\text {nd }}$ Ed. John Wiley \& Sons, Inc., 1975. 